\title{
Transcatheter Closure of Anomalous Systemic Arterial Supply in a Child with Pulmonary Hypertension
}

\author{
Pulmoner Hipertansiyonlu Bir Çocukta Transkateter Yolla Kapatılan Anormal Sistemik Arter
}

\section{Cemşit Karakurt $^{1}$, Fazlı Serkan Çelik ${ }^{1}$, Ahmet Sığırcı ${ }^{2}$}

${ }^{1}$ Department of Pediatric Cardiology, Inonu University, Faculty of Medicine, Malatya, Turkey

${ }^{2}$ Department of Radiology, Inonu University, Faculty of Medicine, Malatya, Turkey

\section{ABSTRACT}

Anomalous systemic arterial supply is a rare condition and it's commonly seen in patients with Scimitar syndrome. A systemic arterial supply to a normal lung without anomaly is a rare variant of bronchopulmonary sequestration and it is characterized by normal pulmonary parenchymal tissue and bronchial connection. The lesion was classified by Pryce as type 1.Common clinical symptoms are chest pain, dyspnea, frequent lower respiratory infection, pulmonary hypertension, hemoptysis, and heart failure. The treatment may be surgical or transcatheter embolization. In this report we described a patient, a 6-year-old boy with Down syndrome and pulmonary hypertension, who had anomalous systemic artery supply to the left lower lob of the lung and its treatment with transcatheter closure by using a vascular plug II.

Key Words: Anomalous systemic arterial supply, transcatheter closure, pulmonary hypertension

Received: 03.18.2014

Accepted: 05.14.2014

\section{ÖZET}

Anormal sistemik arter nadir görülen bir durum olup sıklıkla Scimitar sendromlu olgularda görülmektedir. Normal akciğer dokusu ile birlikte görülen anormal sistemik arter bronkopulmoner sekestrasyonun bir varyantı olarak kabul edilir ve normal akciğer parankimi ve bronşiyal bağlantı ile karakterizedir. Bu durum ilk kez Pryce tarafindan Pryce tip 1 olarak sınıflandırılmıştır. En sık görülen klinik bulgular göğüs ağrısı, dispne, sık alt solunum yolu enfeksiyonu, hemoptizi ve kalp yetersizliğidir. Bu hastalarda anormal sistemik arter cerrahi veya transkateter yolla tedavi edilebilir. Bu sunumda kliniğimize sık alt solunum yolu enfeksiyonu geçirme şikayeti ile başvuran ve pulmoner hipertansiyon saptanan 6 yaşında Down sendromlu bir olguda sol alt lobu besleyen anormal sistemik arter saptanan ve transkateter yolla başarılı şekilde kapatılan bir olgu sunulmuştur.

Anahtar Sözcükler: Anormal sistemik arter, transkateter kapatma, pulmoner hipertansiyon

Geliş Tarihi: 18.03.2014

Kabul Tarihi: 14.05.2014

\section{INTRODUCTION}

Anomalous systemic arterial supply is a rare condition and it's commonly seen in patients with Scimitar syndrome $(1,2)$. A systemic arterial supply to a normal lung without pulmonary parenchymal tissue anomaly is a less common variant of bronchopulmonary sequestration (3). In this report we presented a 6-year-old boy with Down syndrome and pulmonary hypertension who has anomalous systemic arterial supply to the left posterobasal segment of the lung. In this case we embolized anomalous systemic arterial artery by using an Amplatzer vascular plug II after balloon test occlusion.
A 6-year-old boy with Down syndrome was referred to our hospital due to dyspnea, cyanosis, and recurrent lower respiratory tract infection. We learned from the patient history that the patient had been hospitalized 3 times before addmission due to lower tract infection.

During the examination of the patient findings related to Down syndrome and cyanosis were detected. Respiratory rate, heart rate, and oxygen saturation of the patient were found as $50 /$ minute, $130 /$ minute, and $85 \%$, respectively. Cardiac examination showed an increased intensity of the second heart sound.

\section{CASE REPORT}

Address for Correspondence / Yazışma Adresi: Cemşit Karakurt, MD, Inonu University, Faculty of Medicine Department of Pediatric Cardiology, Malatya, Turkey Phone: +90 4223410660 E-mail: ckarakurt@yahoo.com

CTelif Hakkı 2014 Gazi Üniversitesi Tıp Fakültesi - Makale metnine http://medicaljournal.gazi.edu.tr/ web adresinden ulaşılabilir.

(C) Copyright 2014 by Gazi University Medical Faculty - Available on-line at web site http://medicaljournal.gazi.edu.tr/

doi: http://dx.doi.org/10.12996/gmi.2014.38 
Electrocardiography (ECG) revealed a right axis deviation and right ventricular hypertrophy. A chest radiograph showed retrocardiac infiltrations.

Echocardiographic examination showed a $10 \mathrm{~mm}$ secundum type atrial septal defect (ASD) and pulmonary hypertension. Right ventricular systolic pressure was calculated as $100 \mathrm{mmHg}$ echocardiographically according to the tricuspide insufficiency. Echocardiographic examniantion also showed that right to left shunt via ASD. A contrast computerized tomography of the thorax showed normal lung segments except for the ectasia of the left lower pulmonary veins. During cardiac catheterization pulmonary artery pressure (PAP) was measured as $100 / 57-84 \mathrm{mmHg}$, aorta pressure as $103 / 59-85$ $\mathrm{mmHg}$, and Qp/Qs was calculated as 1 . Selective angiograms of pulmonary arteries showed a normal pulmonary vein dreinage, however cardiac catheterization demonstrated an anomalous artery arising from the lower descending thoracic aorta and supplying the posterobasal segment of the left lower lobe (Figure 1). Narrowest diameter of this anomalous systemic artery was measured as $10.7 \mathrm{~mm}$. Despite the small arteries arising from the left pulmonary, which were supply the left lower lobe of the lung (Figure 2), we decided to perform a balloon test occlusion. 10 minutes after balloon occlusion of anomalous artery with a $11 \times 2 \mathrm{~cm}$ Tyshak II balloon catheter, the PAP decreased to $67 / 16-44 \mathrm{mmHg}$ without any changes in the systemic arterial pressure and oxygen saturation (Figure 3 ). After the balloon test occlusion a 6 French guiding catheter was placed into the anomalous systemic artery which was then embolized by using a $12 \times 10$ Amplatzer vascular plug II (Figure 4). There were no complications during and after the catheterization. Following the administration of ilioprost for pulmonary hypertension, the patient was discharged. We did not observe any complication or lower respiratory infection during the 4-month follow-up period. At the end of 4 th month right ventricular systolic pressure was calculated as $60 \mathrm{mmHg}$ on echocardiographic examination. Shunt direction returned to left to right via ASD after transchateter closure.

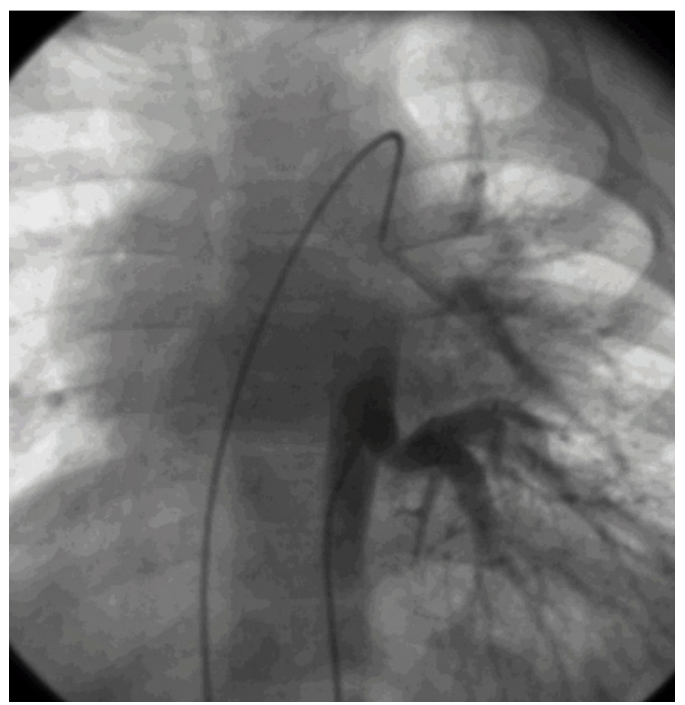

Figure 1. Aortogram shows anomalous systemic artery supply to posterobasal segment of left lung.

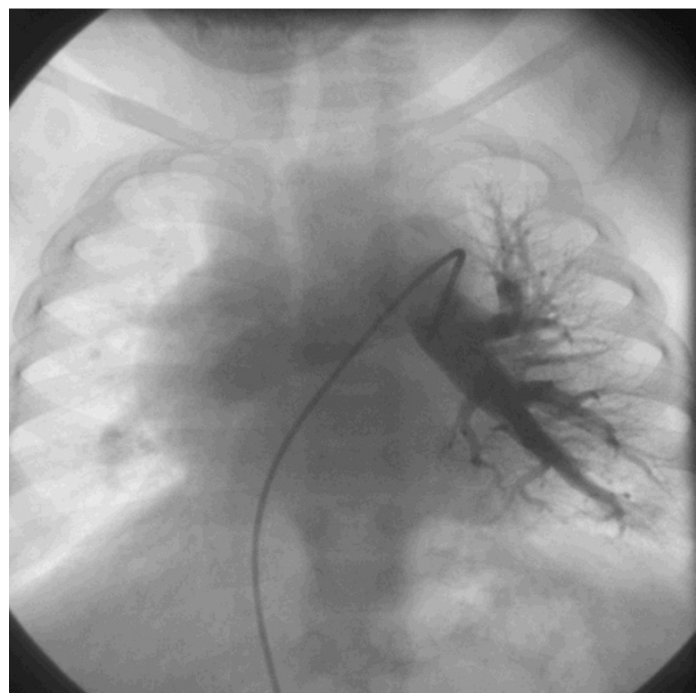

Figure 2. Selective angiogram of left pulmonary artery shows that small arteries arising from the left pulmonary also supply posterobasal segment of left lung.

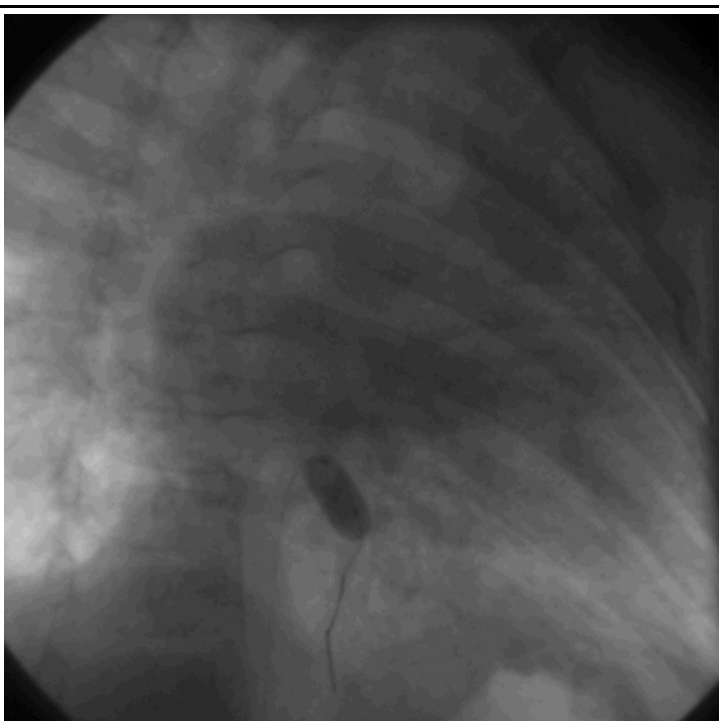

Figure 3. Picture shows test occlusion with ballon catheter.

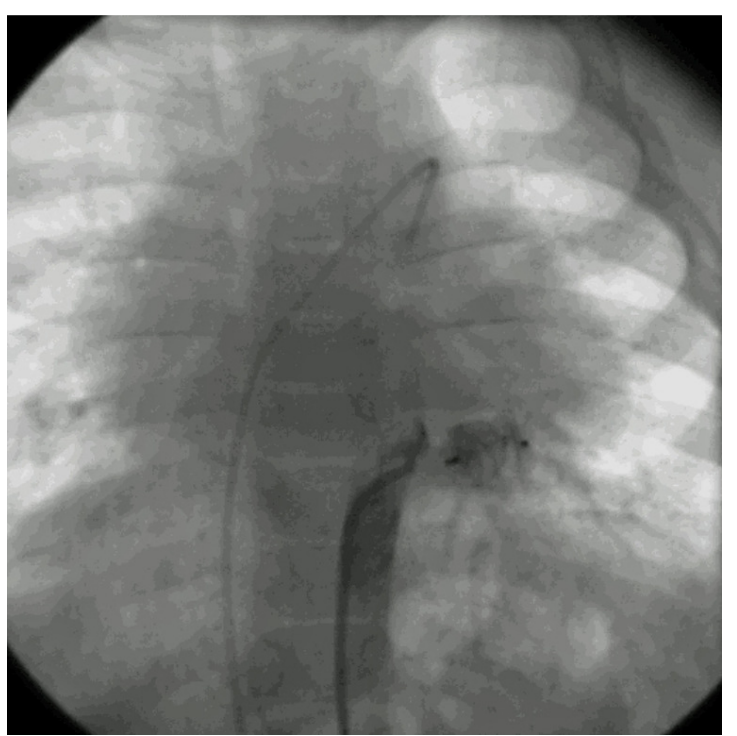

Figure 4. Aortogram shows complete occlusion of anomalous systemic arteries after occlusion by using with vascular plug II.

\section{DISCUSSION}

A systemic arterial supply to a normal lung without anomaly is a rare variant of bronchopulmonary sequestration. It is classified into two types: isolated systemic arterial supply to a normal lung and systemic arterial supply associated with a normal pulmonary artery. In our patients the left lower basal segment of the left lung is primarly supplied by an anomalous systemic artery originating from the descending aorta but it also has small arteriel supplies originiating from the left pulmonary artery. Since the original classification of pulmonary sequestration was first made by Pryce et al this abnormality is defined as Pryce type 1 . In type 2 , the systemic artery supplies both the normal and abnormal lung, having no communication with the tracheobronchial tree (3). In type 3, only the noncommunicating abnormal lung receives the aberrant systemic artery. This condition is considered as the reason for the failure of regression of the primitive aortic branches to the developing lung bud $(4,5)$.

As in our case, the basal segments of the left lower lobe are the most commonly affected sites, although other sites can rarely be affected $(5,6)$. The systemic artery most commonly arises from the thoracic aorta, but can arise from the abdominal aorta or celiac axis and even more rarely from the left subclavian and internal mammary artery, as well (7).

Most patients are asymptomatic. The most common symptom is hemoptysis and it is usually seen in adults and because of higher pressure of systemic circulation compared to pulmonary circulation. Other manifestations are dyspnea, murmur in the lower chest, and congestive heart failure due to the left heart overload. The origin and course of an aberrant artery can be demonstrated by computerized tomography or conventional angiography. 
Treatment options are surgery (lobectomy and segmentectomy) or transcatheter closure of the anomalous artery with coils or devices, when the involved segment has dual blood supply (2). In our case, we decided on transcatheter closure after balloon test occlusion and the anomalous systemic artery was closed successfully with a vascular plug II. Although the bronchial arteries are also involved in the lung supply, in our opinion, balloon test occlusion of anomalous artery before transcatheter closure can give useful data whether ischemia will be seen or not after transcatheter closure.

\section{Conflict of Interest}

No conflict of interest was declared by the authors.

\section{REFERENCES}

1. Noble S, Miro J, Ibrahim R. Transcatheter embolization of anomalous systemic arterial supply with Amplatzer vascular plugs II in Scimitar syndrome. Catheter Cardiovasc Interv 2012;80:477-81.

2. Bentham JR, Wilson N. Occlusion of anomalous systemic arterial supply in Scimitar syndrome using the new Amplatz vascular plug IV. Cardiol Young 2010;20:349-50.
3. Pryce DM. Lower accessory pulmonary artery with intralobar sequestration of lung; a report of seven cases. J Pathol Bacteriol 1946;58:457-67.

4. Hiramatsu $M$, Iwashita $M$, Inagaki $T$, Matsudaira $H$, Hirano J, Odaka $M$, et al. Anomalous systemic arterial supply to separate lingular and basal segments of the lung: an anatomic consideration. Ann Thorac Surg 2009;88:1358-60.

5. Ellis K. Fleischner lecture. Developmental abnormalities in the systemic blood supply to the lungs. AJR Am J Roentgenol 1991;156:669-79.

6. Miyake H, Hori Y, Takeoka H, Takuma M, Kawagoe T, Mori H. Systemic arterial supply to normal basal segments of the left lung: characteristic features on chest radiography and CT. AJR Am J Roentgenol 1998;171:38792.

7. BrühImann W, Weishaupt D, Goebel N, Imhof E. Therapeutic embolization of a systemic arterialization of lung without sequestration Eur Radiol. 1998;8: 355-8.

8. Saida T, Ninomiya H, Hojo F, Nakayama M, Yamauchi T, Saida $Y$. Systemic arterial supply to the normal basal segments of the left lower lobe treated by coil embolization, with long-term follow-up . Radiat Med. 2006 ; 24 : 365-8. 